\title{
Description of a new species of Parancistrus (Siluriformes: Loricariidae) from the rio Xingu, Brazil
}

\author{
Lúcia H. Rapp Py-Daniel and Jansen Zuanon
}

Parancistrus nudiventris, new species, is described and compared with the congener $P$. aurantiacus. The new species has only been recorded from rio Xingu and can be distinguished from $P$. aurantiacus by having a naked abdomen (plated in $P$. aurantiacus), the presence of bluish dots in living specimens or spotted in preserved specimens (uniformly dark or clear brown or mottled, never spotted in P. aurantiacus), larger interbranchial distance (39-56\% in HL vs. $24.9-39.5 \%$ in P. aurantiacus), narrower interorbital distance (26.8-38\% in HL vs. 38.5-43.1\% in P. aurantiacus). Parancistrus nudiventris also has buccal teeth more conspicuous than in $P$. aurantiacus. Main skeletal differences include the presence of a strong condyle on the lateral ethmoid for articulation with the metapterygoid in $P$. nudiventris (not seen in P. aurantiacus); anguloarticular processes short in P. nudiventris (long in P. aurantiacus); opercle with odontodes, partly exposed in P. nudiventris (completely embedded in skin in P. aurantiacus).

Parancistrus nudiventris, espécie nova, é descrita e comparada com P. aurantiacus. Esta nova espécie só foi registrada no rio Xingu e pode ser diferenciada de $P$. aurantiacus pela ausência de placas no abdome (abdome totalmente coberto em $P$. aurantiacus), pela presença de pontos azulados nos exemplares recém-coletados ou pontilhado claro nos exemplares preservados (em P. aurantiacus a coloração é uniformemente marrom escura ou clara, ou manchada, nunca pontilhada), distância interbranquial mais larga (39-56\% no comprimento padrão vs. 24.9-39.5\% em P. aurantiacus), distância interorbital mais estreita (26.8-38\% no comprimento padrão vs. $38.5-43.1 \%$ em P. aurantiacus). Parancistrus nudiventris também apresenta dentes bucais mais conspícuos do que P. aurantiacus. As principais diferenças osteológicas incluem a presença de um forte côndilo no etmóide lateral para articulação com o metapterigóide em P. nudiventris (côndilo este não observado em P. aurantiacus); processos no ângulo-articular curtos em $P$. nudiventris (mais longos em $P$. aurantiacus); opérculo parcialmente exposto e com odontódios em $P$. nudiventris, mas completamente incluso na pele em P. aurantiacus.

Key words: Parancistrus nudiventris, Freshwater fishes, Amazon basin, Natural History, Neotropical catfishes.

\section{Introduction}

Recent expeditions to the rio Xingu, the last eastern large tributary of the rio Amazonas, Brazil, uncovered specimens of a new species of the loricariid genus Parancistrus, described herein. In the most recent revision of the genus (Rapp PyDaniel, 1989), two previously described species of Parancistrus (P. nigricans and P. vicinus) were placed in synonymy with the type species, $P$. aurantiacus. Many specimens of Parancistrus are often misidentified at the generic level (as Baryancistrus or Oligancistrus or in other genera), and, more frequently misidentified at species level. Currently, a considerable part of the loricariid input in the international aquarium trade originates from the rio Xingu and misidentification is becoming a big issue in Brazilian export regulations for aquarium trade purposes.
Parancistrus aurantiacus has been recorded from the rio Ucayali and rio Araguaia, from the Amazon (without a precise locality) (Castelnau, 1855) and from the rio Tocantins (Rapp Py-Daniel, 1989). Recent collections also yielded more specimens of $P$. aurantiacus from the rio Araguaia. The new species of Parancistrus has been collected only in the rio Xingu.

Herein we describe this new species of Parancistrus and provide some skeletal and ecological data.

\section{Material and Methods}

Morphological accounts are summarized from Bleeker (1862), Regan (1904), and Rapp Py-Daniel (1989). All measurements were taken with a dial caliper. One double-stained (Pothoff, 1984) dissected specimen of each species of Parancistrus was used for osteological comparisons. Mea-

Coordenação de Pesquisas em Biologia Aquática, Instituto Nacional de Pesquisas da Amazônia - INPA, Manaus, Amazonas, Brazil. e-mail: (LRP) rapp@inpa.gov.br; (JZ) zuanon@inpa.gov.br 


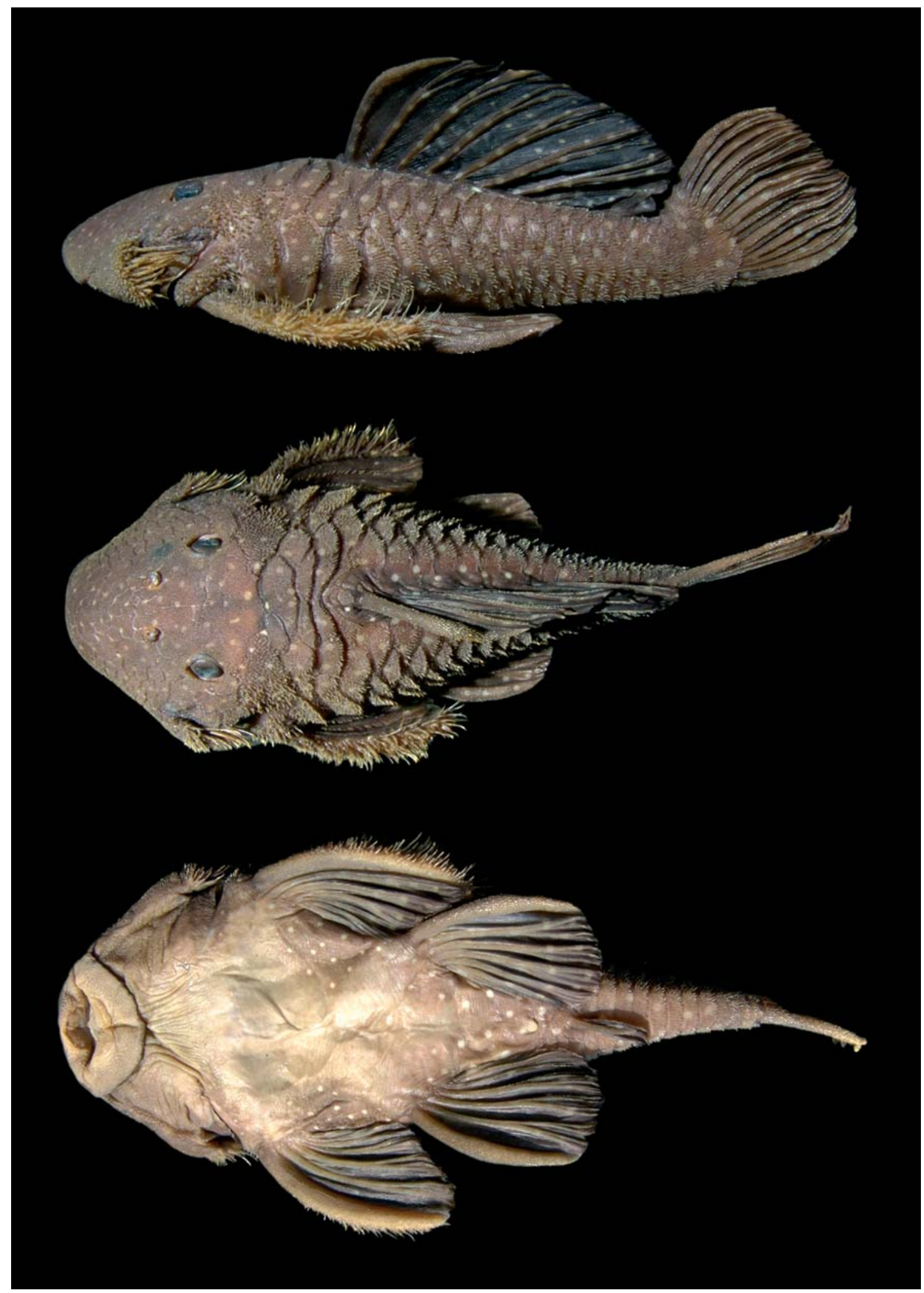

Fig. 1. Parancistrus nudiventris. Lateral, dorsal, and ventral view of the holotype (INPA 15037, $152 \mathrm{~mm}$ SL).

surements and counts were made according to Rapp Py-Daniel (1989) with the addition of: head depth - measured at supraoccipital; body depth - measured at dorsal fin insertion; body width at dorsal fin - measured at point of fin insertion; body width at anal fin - measured at insertion of fin; postdorsal length - measured from last dorsal-fin ray to end of caudal peduncle; postanal length - measured from last anal-fin ray to end of caudal peduncle; dorsal spine length - from base to 

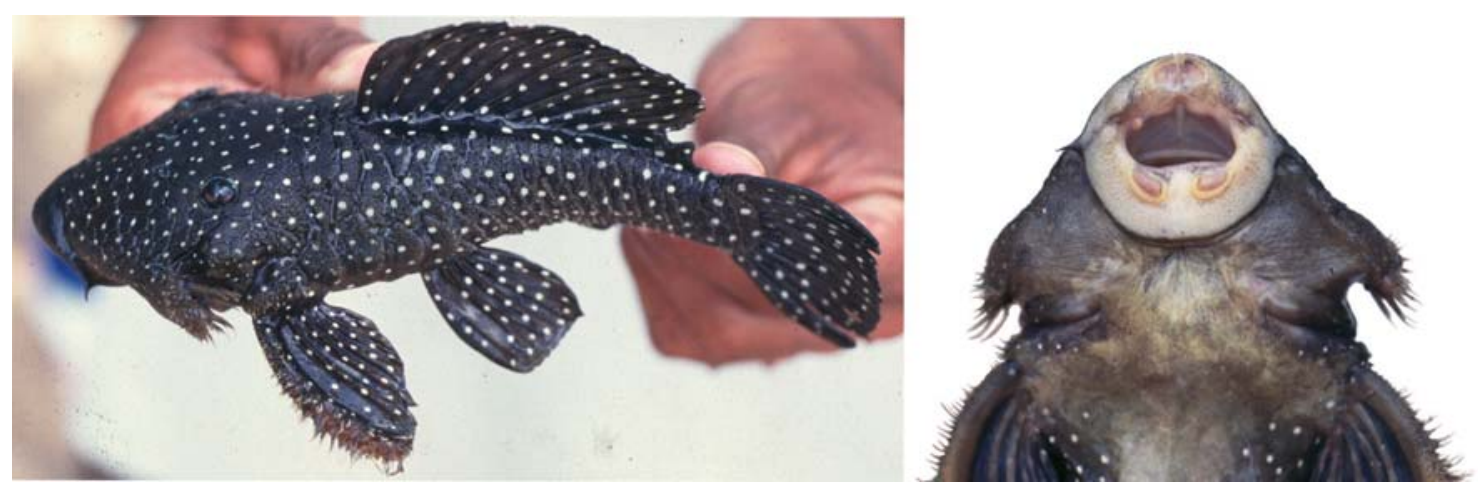

Fig. 2. Parancistrus nudiventris. Living color and detail of mouth of the holotype (INPA 15037, $152 \mathrm{~mm} \mathrm{SL).}$

tip of spine; pectoral spine length - from base to tip of spine; first pelvic fin ray - whole extension of first unbranched ray; first and second anal fin rays - extension of first and second unbranched rays; and interbranchial length - shortest distance between gill openings ventrally. Institutional abbreviations are as listed in Leviton et al. (1985). Osteological nomenclature follows Schaefer (1987), Armbruster (2004), and unpublished dissertations of Schaefer (1986), Armbruster (1997), and Rapp Py-Daniel (1997).

Parancistrus nudiventris was observed during diurnal and nocturnal snorkeling sessions by one of us (JZ) at several rapids of the rio Xingu near Altamira, Pará State. The underwater observations included activity period, foraging tactic, microhabitat characteristics, and type of diurnal shelters. The dietary data were obtained through analyses of stomach contents of two preserved specimens.

\section{Parancistrus Bleeker, 1862}

Diagnosis. Parancistrus can be characterized by the presence of a membranous connection between the dorsal and adipose fins, cephalic and body scutes not carinate and a large gill opening. Armbruster (1997) additionally diagnosed the genus based on posterior deflection of the hyomandibula and presence of fleshy folds along the dorsal-fin base of nuptial males. Parancistrus can be further distinguished from Ancistrus and Chaetostoma by having a plated snout and from all other genera of the Ancistrini (sensu Armbruster, 2004), except Baryancistrus, Oligancistrus, and Spectracanthicus, by the connection between dorsal and adipose fins; from Baryancistrus, Oligancistrus, and Spectracanthicus, by the large gill openings.

\section{Parancistrus nudiventris, new species} Figs. 1, 2

Holotype. INPA 15037 (152 mm SL); Brazil; Pará State; rio Xingu, bedrock at ilha do Bacabal, 3²3'19"S, 51²4'24"W; J. Zuanon, 8 Sep 1997.

Paratypes. (25 specimens) All localities in Brazil, Pará State, rio Xingu: INPA 3941 (5, 102-131 mm SL), Furo do Tucum Seco near Arroz Cru, 325'6"S, 51 $555^{\prime} 8^{\prime \prime} \mathrm{W}$; L. Rapp Py-Daniel and J. Zuanon, Oct 1990. INPA 3962 (5, 60-114 mm SL), cachoeira do Kaituká, cast-net, 3³3'47"S, 51²51'20"W; L. Rapp Py-Daniel and J. Zuanon, Oct 1990. INPA 4095 (1, 117 $\mathrm{mm}$ SL), bedrock at ilha de Babaquara, collected manually, $3^{\circ} 25^{\prime} 44^{\prime \prime S}, 52^{\circ} 14$ '25"W; J. Zuanon, Sep 1997. INPA 15038 (1, $149 \mathrm{~mm}$ SL), bedrock at ilha do Bacabal, collected manually, 3²3'19"S, 51²4'24"W; J. Zuanon, Sep 1997. INPA 15042 (1,

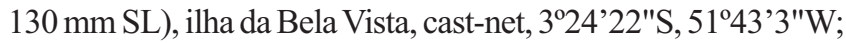
J. Zuanon, Sep 1997. INPA 15043 (1, 151 mm SL), corredeiras do Jutaizão, cast-net, $3^{\circ} 16^{\prime}$ '42"S, 52²'20"W; J. Zuanon, Sep 1997. INPA 15044 (1, $175 \mathrm{~mm} \mathrm{SL})$, bedrock at ilha do Sr. Izaltino, gill-net, 3¹6'21"S, 52²12'7"W; J. Zuanon, Sep 1997. INPA 15045 (1, $153 \mathrm{~mm} \mathrm{SL})$, bedrock at ilha do Sr. Izaltino, collected manually, 316’21"S, 52¹2'7"W; J. Zuanon, Sep 1997. INPA 15046 (1,140 mm SL), igarapé Bacajá, cachoeira Alpercata, castnet, 3²9'53"S, 5143'00"W; J. Zuanon, Sep 1996. INPA 15047 (2, 96-135 mm SL), bedrock at ilha do Sr. Izaltino, gillnet, 316’21"S, 52¹2'7"W. INPA 17961 (2, 53-150 mm SL), Costa Júnior, collected manually, 3²9'28"S, 52¹9'7"W; J. Zuanon, Sep 1996. INPA 17960 (3, 1 c\&s: 58-81 mm SL), Altamira, specimens from aquarium trade, approx. $3^{\circ} 12^{\prime} \mathrm{S}, 52^{\circ} 24^{\prime} \mathrm{W}$; A. Uchoa, Apr-Sep 1997. ZUEC 4538 (1, 100 mm SL), Furo do Ramiro, 0315'21"S, 5205’06"W; J. Zuanon, Sep 1997.

Diagnosis. Parancistrus nudiventris is distinguished from $P$. aurantiacus (the only other valid species of Parancistrus) by the lack of abdominal plates, larger interbranchial distance (39-56\% in HL vs. 24.9-39.5\% in P. aurantiacus), narrower interorbital distance (26.8-38\% in HL vs. $38.5-43.1 \%$ in $P$. aurantiacus), buccal teeth more conspicuous, and shorter posterior dentary processes. Skeletal differences include the presence of a strong condyle on the lateral ethmoid for articulation with the metapterygoid in $P$. nudiventris (not seen in $P$. aurantiacus); anguloarticular processes short in $P$. nudiventris (long in P. aurantiacus); opercle with odontodes, partly exposed in $P$. nudiventris (completely embedded in skin in $P$. aurantiacus). Parancistrus nudiventris also has a different pattern of coloration from $P$. aurantiacus: alive, the fish is covered by small bluish white spots; in preserved specimens, these spots become yellowish. Parancistrus aurantiacus can be uniformly darkly colored or covered by large pale blotches or even marbled. 
Table 1. Counts and morphometrics of Parancistrus nudiventris and P. aurantiacus ( $\mathrm{H}=$ holotype). Holotype of $P$. aurantiacus is a deformed, stuffed specimen, so data not included in mean.

\begin{tabular}{|c|c|c|c|c|}
\hline & \multicolumn{2}{|c|}{ P. nudiventris $(\mathrm{n}=24)$} & \multicolumn{2}{|c|}{ P. aurantiacus $(\mathrm{n}=20)$} \\
\hline & Range (H) & Mean & Range (H) & Mean \\
\hline Standard length $(\mathrm{mm})$ & $53-175(152)$ & 114.8 & $73-135(192.5)$ & 99.9 \\
\hline \multicolumn{5}{|c|}{ Percent of Standard Length } \\
\hline Head length & $34.5-41.8(35.7)$ & 38.1 & $36.4-42.1(36.6)$ & 39.6 \\
\hline Head depth & $17.0-21.8(19.2)$ & 19.7 & $17.4-25.0(22.8)$ & 21.2 \\
\hline Head width & $35.3-41.7(39.5)$ & 39.2 & $37.3-44.5(36.4)$ & 40.6 \\
\hline Body depth & $15.7-24.0(21.8)$ & 20.7 & $16.6-27.1(28.8)$ & 22.6 \\
\hline Body width at dorsal & $29.4-36.0(33.0)$ & 32.7 & $32.1-40.7(33.8)$ & 36.6 \\
\hline Body width at anal & $12.6-19.8(15.8)$ & 16.3 & $14.8-22.1(-)$ & 18.8 \\
\hline Predorsal length & $42.4-49.8(43.8)$ & 46.1 & $42.7-49.8(45.2)$ & 46.6 \\
\hline Postdorsal length & $16.0-23.0(21.1)$ & 20.5 & $17.2-24.5(19.4)$ & 20.8 \\
\hline Postanal length & $21.7-25.7(25.7)$ & 23.7 & $18.3-25.8(21.2)$ & 23.2 \\
\hline Dorsal spine length & $18.6-28.3(23.4)$ & 23.6 & $20.1-26.5(16.3)$ & 23.3 \\
\hline Pectoral spine length & $24.6-30.0(29.0)$ & 27.2 & $26.1-30.8(27.1)$ & 28.5 \\
\hline $1^{\text {st }}$ Pelvic ray length & $21.4-26.3(22.8)$ & 23.5 & $21.2-26.0(18.0)$ & 24.1 \\
\hline Dorsal base length & $26.0-34.7(28.9)$ & 30.6 & $27.4-45.9(41.0)$ & 39.4 \\
\hline \multicolumn{5}{|c|}{ Percent of Head Length } \\
\hline Snout length & $62.8-70.9(70.7)$ & 66.8 & $61.9-70.3(66.8)$ & 66.1 \\
\hline Interorbital width & $26.8-38.0(37.1)$ & 33.8 & $38.5-43.1(41.9)$ & 41.3 \\
\hline Orbital diameter & $13.5-18.1(15.9)$ & 15.6 & $13.5-16.4(10.9)$ & 14.9 \\
\hline Dentary length & $7.5-12.9(8.7)$ & 10.1 & $7.9-12.3(-)$ & 10.3 \\
\hline Interbranchial width & $39-56.1(53.5)$ & 48.5 & $24.9-39.5(33.9)$ & 29.4 \\
\hline Caudal peduncle depth & $10.5-13.1(11.5)$ & 12.0 & $11.5-13.9(14.3)$ & 12.9 \\
\hline \multicolumn{5}{|c|}{ Counts } \\
\hline Premaxilary teeth & $6-21(21)$ & 14.2 & $4-16(-)$ & 11.9 \\
\hline Dentary teeth & $9-35(26)$ & 23.7 & $8-21(-)$ & 13.6 \\
\hline Dorsal fin rays & $\mathrm{i}+7(\mathrm{i}+7)$ & $i+7$ & $\mathrm{i}+7(\mathrm{I}+7)$ & $i+7$ \\
\hline Pectoral fin rays & $i+6(i+6)$ & $\mathrm{i}+6$ & $\mathrm{i}+6(\mathrm{I}+6)$ & $\mathrm{i}+6$ \\
\hline Pelvic fin rays & $i+5(i+5)$ & $i+5$ & $i+5(i+5)$ & $i+5$ \\
\hline Anal fin rays & $\mathrm{i}+4(\mathrm{i}+4)$ & $\mathrm{i}+4$ & $\mathrm{i}+4(\mathrm{i}+4)$ & $\mathrm{i}+4$ \\
\hline Caudal fin rays & $\mathrm{i}+14+\mathrm{i}(\mathrm{i}+14+\mathrm{i})$ & $\mathrm{i}+14+\mathrm{i}$ & $\mathrm{i}+14+\mathrm{i}(\mathrm{i}+14+\mathrm{i})$ & $\mathrm{i}+14+\mathrm{i}$ \\
\hline Lateral line plates & $21-23(22)$ & 22 & $22-23(22)$ & 22.6 \\
\hline Caudal peduncle plates & $9-11(11)$ & 10.1 & $10-12(9)$ & 10.7 \\
\hline
\end{tabular}

Description. Body proportions and meristics in Table 1. Head and body short, broad and flat, tapering both anteriorly and posteriorly. Maximum body width at pectoral girdle. Cleithrum covered by strong odontodes. Body plates hispid, not carinate. Predorsal plates organized in series of pairs in some specimens, or without any organization. Head without keels or ridges. Snout triangular, completely covered by small plates.

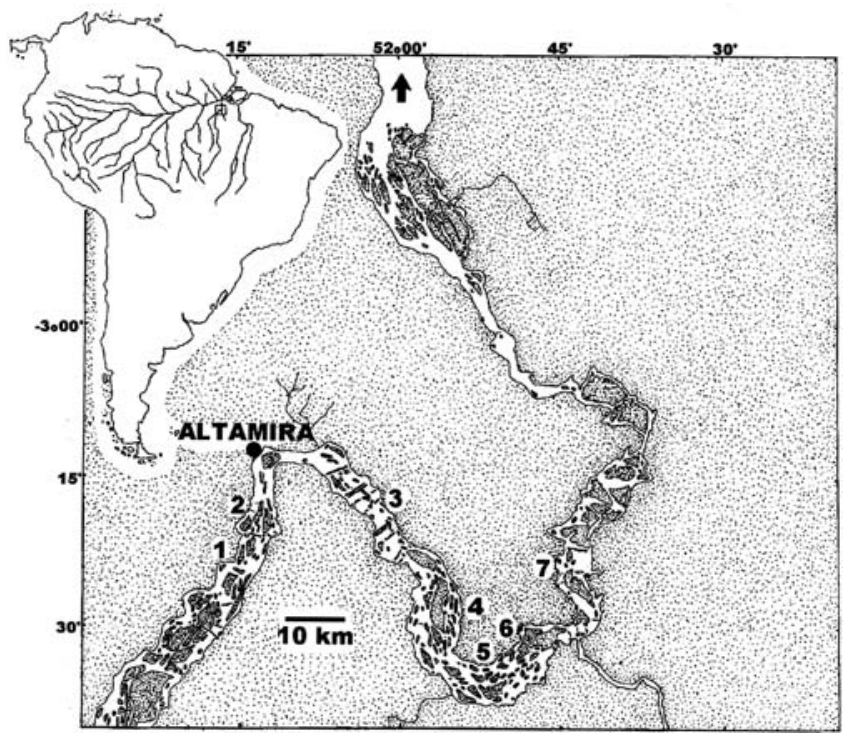

Fig. 3. Distribution of Parancistrus nudiventris.
Interorbital area flat. Orbit large and round. Supraoccipital conspicuously distinct from pterotic-supracleithrum.

Evertible cheek plates with associated hypertrophied odontodes and disposed as unique block ligamentously connected to opercle. Opercular movements causes expansion of opercular block, thereby everting odontodes. Opercle with small area exposed with short odontodes. Subpreopercle not reaching border of head.

Mouth wide, lips papillate. Upper lip smooth externally, but densely papillated internally. Maxillary barbels very short. Premaxillae round, reduced and ligamentously attached to each other. Dentaries short and spaced widely apart. Buccal teeth villiform, well developed, not numerous and weakly cuspidate. Gill opening wide, branchial chamber large. From mouth to anus, ventral surface completely naked, except for some scattered platelets disposed close to pectoral-fin insertion.

Dorsal fin long and low, connected to adipose fin by thick membrane. Pectoral and pelvic fins well developed. Pectoral spine stiff and strong, covered by long piercing odontodes on large specimens. Anal fin extremely reduced. Caudal fin truncate to slightly emarginate. Caudal peduncle flat ventrally.

Metapterygoid channel complete, ending on articulation with lateral ethmoid. Quadrate abutted to metapterygoid. Opercle elongate, almost straight, with small area with odontodes. Preopercle with exposed area with odontodes. 


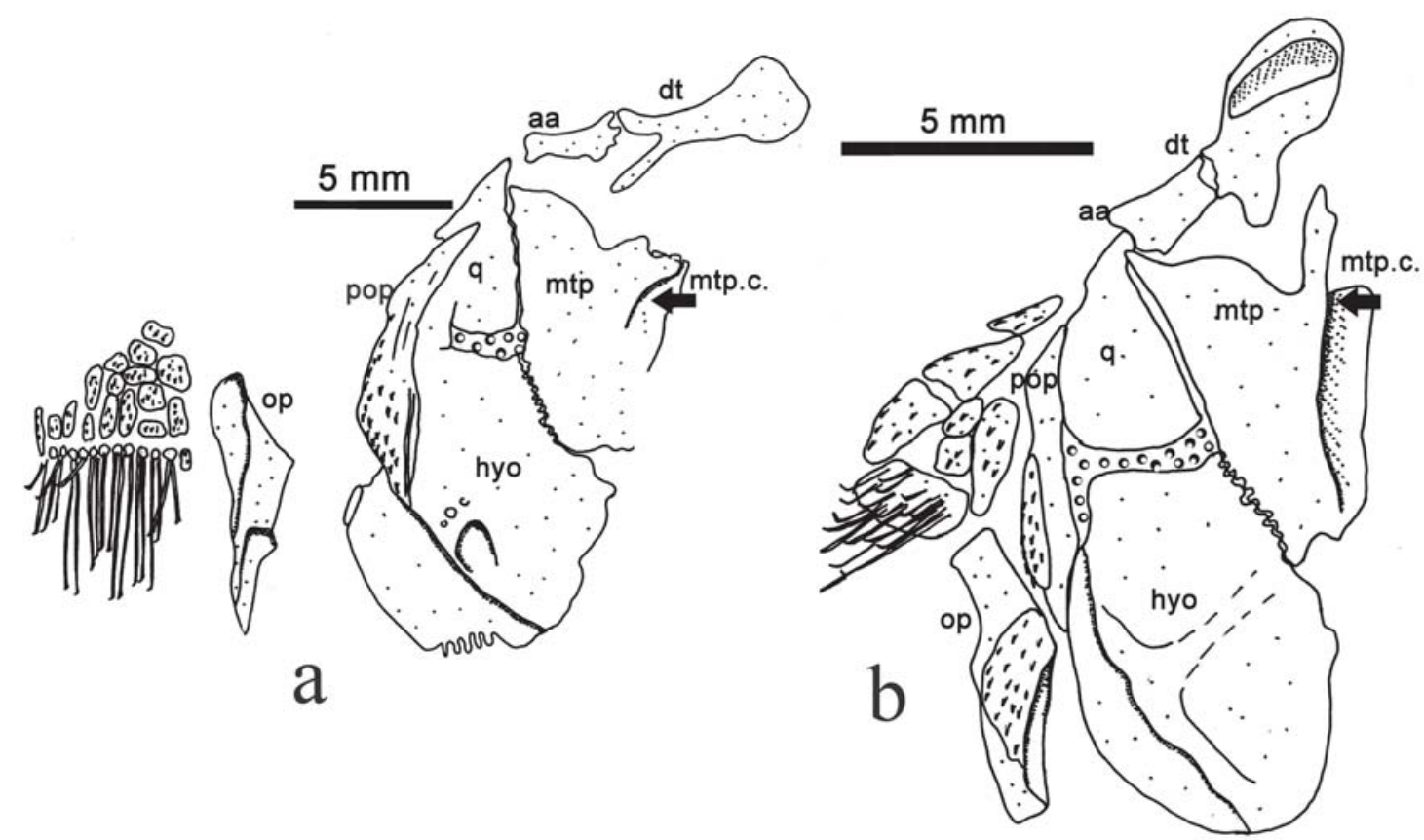

Fig. 4. Suspensorium, dorsal view. a. Parancistrus aurantiacus; b. Parancistrus nudiventris. aa $=$ angulo-articular, dt $=$ dentary, hyo $=$ hyomandibular, $\mathrm{mpt}=$ metapterygoid, mpt.c. $=$ metapterygoid channel, op $=$ opercle; pop $=$ preopercle, $\mathrm{q}=$ quadrate.

Basipterygia anterior processes curved. Basipterygia connected by three sutures (additional suture between mesial anterior basipterygia processes). Lateral line complete, not entering supracaudal plates.

Color in alcohol. Body and fins evenly dark brown covered by minute yellowish spots. Spots more concentrated and conspicuous on dorsal and caudal fins. Head and abdomen poorly spotted.

Color in life. Overall body color dark grey to olive, with scattered small bluish white dots (Fig. 2).

Sex dimorphism. Sexual dimorphism in Parancistrus nudiventris is expressed by the presence of strong spines on

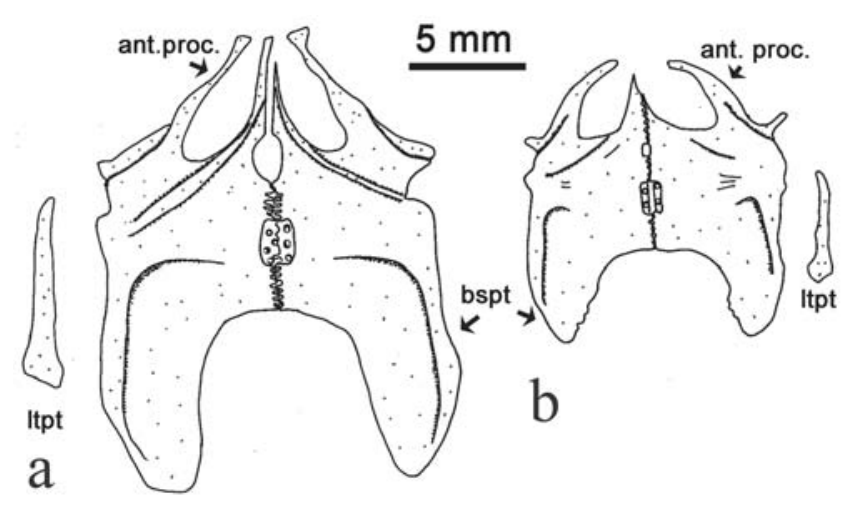

Fig. 5. Basipterygia (bspt), anterior processes (ant. proc.) and lateropterygium (ltpt), dorsal view. a. Parancistrus aurantiacus; b. Parancistrus nudiventris. the pectoral fin spine, the cheek area and body plates of sexually mature males. Fleshy folds were not observed in the examined material despite the presence of large mature males in the type series.

Geographic distribution. All specimens examined of Parancistrus nudiventris are from the rio Xingu (Fig. 3).

Ecological notes. Parancistrus nudiventris is a rheophilic species, found in rocky-bottom areas subjected to moderate to strong current (40 to $190 \mathrm{~cm} / \mathrm{sec}$ ). Specimens were found individually or in pairs in shelters under boulders or in narrow cracks on submerged rocks up to $2 \mathrm{~m}$ deep. Young specimens (up to $5 \mathrm{~cm} \mathrm{SL}$ ) were observed under flat rocks over the bottom, usually sharing the shelter with specimens of Baryancistrus spp., Oligancistrus sp., O. punctatissimus, Hopliancistrus tricornis, Ancistrus sp., A. ranunculus, Peckoltia vittata and Pseudancistrus aff. barbatus.

Parancistrus nudiventris is a nocturnal fish that feeds by grazing over rock surface, browsing algae and other food items off the periphyton. Analysis of the stomach contents revealed the presence of algae as the most frequent food ingested, and included mainly diatoms. Other food items were cyanobacteria, plant remains, bryozoans, larvae of aquatic insects (most chironomids), microcrustaceans, and few small molluscs; sand grains and silt were also recorded. Dissected specimens had long digestive tracts, approximately 20 times the SL, characteristic of algae-feeding fishes. The consumption by $P$. nudiventris of food items found loosely attached to the rocks characterize this species as a comber, following the feeding-strategy classification proposed for African Rift Lake cichlids ( $c f$. Konings, 1989; Yamaoka, 1997). 
Table 2. Summary of differences between Parancistrus aurantiacus and P. nudiventris.

\begin{tabular}{lcc}
\hline & P. aurantiacus & P. nudiventris \\
\hline abdomen & plated & naked \\
dentary posterior processes & long & short \\
strong lateral ethmoid condyle & no & yes \\
metapterygoid channel & short, incomplete & long, ending at articulation site with lateral ethmoid \\
quadrate-metapterygoid connection & loose suture & abutted \\
opercle & unexposed & partly exposed, bearing odontodes \\
upper pharyngeal plates & not toothed, just crenulated & fully toothed on the contact area with the lower pharyngeal plate \\
basipterygium anterior process & straight & curved \\
basipterygia sutures & 2 & 3 \\
\hline
\end{tabular}

Etymology. The name nudiventris is derived from the Latin nudus, naked, and ventris, belly.

Morphological and skeletal remarks. There are clear differences in body format between $P$. nudiventris and P. aurantiacus. Parancistrus nudiventris is slender, has larger eyes, and has a shorter caudal peduncle, whereas $P$. aurantiacus has a shorter and wider head and wider branchial openings.

Metapterygoid channel (Howes, 1983; Schaefer, 1987) is not completely closed, with tall wall only on the anterior half of the channel in P. aurantiacus. In P. nudiventris the channel is complete and it ends on the articulation site with the lateral ethmoid (Fig. 4). Quadrate loosely sutured to metapterygoid in $P$. aurantiacus and just abutted in $P$. nudiventris. The opercle in P. aurantiacus is elongate and almost straight, embedded in skin and without any odontode. In P. nudiventris, however, the opercle is similar in shape but shows a small area with odontodes. Preopercle with larger exposed area with odontodes in $P$. aurantiacus than in $P$. nudiventris. Anterior process of basipterygium straight in $P$. aurantiacus and curved in $P$. nudiventris (Fig. 5 ). Basipterygia connected by two sutures in $P$. aurantiacus (the anterior and posterior sutures to the cartilage plug) and by three in $P$. nudiventris (additional suture between the mesial anterior basipterygia processes).

Lateral line complete, not entering the supracaudal plates on both P. aurantiacus and P. nudiventris. Table 2 summarizes the main differences described for both species.

\section{Discussion}

The genus Parancistrus can be distinguished from all other Hypostominae by the broad membranous connection between the dorsal and adipose fin associated with an extremely large gill opening. Among loricariids, and more specifically the Ancistrini, other genera have a developed dorsal fin membrane but differ from Parancistrus in other features (see diagnosis for more details). Large gill openings are present in Ancistrus ranunculus Muller et al., 1994 and Rhinelepis spp. but there is no membranous connection between the dorsal and adipose fins.

Comparative material examined: Parancistrus aurantiacus: MNHN A 9452 (holotype of Chaetostomus aurantiacus - specimen stuffed), Ucayali River, Peru; MNHN A 9572 (holotype of Hypostomus vicinus), Ucayali River, Peru; MNHN A 9576 (holo- type of Hypostomus nigricans), Amazon River, Brazil; INPA 787 (159, 16 measured; 92-135 mm SL), rio Tocantins, Pará State, Brazil; INPA 789 (3, 1 c\&s, all measured; 73-88 mm SL), rio Tocantins, Pará State, Brazil; INPA 25302 (1), rio Araguaia, Tocantins State, Brazil; INPA 25303 (1), rio do Côco, afluente do rio Araguaia, Tocantins State, Brazil.

\section{Acknowledgements}

We thank I. Barbosa and family for housing and helping in the field at Altamira, Pará; A. Uchoa for donating specimens from the aquarium trade; L. M. de Sousa for the images of the preserved material; O. M. Ribeiro for editing the map; the IBAMA (Ministério do Meio Ambiente, Brazil) for permission to study and collect fishes at rio Xingu. This work was partly developed during the doctoral studies of JZ at Universidade Estadual de Campinas, SP, Brazil; doctoral scholarship provided by CAPES (Ministério da Educação, Brazil). Field work and equipment facilities were made available from WWF-Brazil and Fundação "O Boticário" de Proteção à Natureza (Brazil). First field trip to rio Xingu (1990 - LRP and JZ) and examination of the type species of Parancistrus aurantiacus (LRP) was made possible by the INPA/ORSTOM (France) Project.

\section{Literature cited}

Armbruster, J. W. 1997. Phylogenetic relationships of the suckermouth armoured catfishes (Loricariidae) with particular emphasis on the Ancistrinae, Hypostominae and Neoplecostominae. Unpublished Ph.D. Dissertation, University of Illinois, Urbana-Champaign.

Armbruster, J. W. 2004. Phylogenetic relationships of the suckermouth armoured catfishes (Loricariidae) with emphasis on the Hypostominae and the Ancistrinae. Zoological Journal of the Linnean Society, 141: 1-80.

Bleeker, P. 1862. Atlas ichthyologique des Indes orientales néêrlandaises, publié sous lês auspices du Gouvernment colonial néêrlndaises: Siluroîdes, Chacoîdes et Hétérobranchoîdes (Fr. Muller, Amsterdam), 2: 1-112, pls. 49-101.

Castelnau, F. 1855. Animaux nouveaux ou rares recueilles pendant l'expédition dans lês parties centrales de l'Amerique du Sud, de Rio de Janeiro à Lima, et de Lima à Pará; executeé par ordre du Govenement français pendant les années 1843 à 1847, sous la direction du comte. Francis de Castelnau. Bertrand, Paris. 106 p. 
Howes, G. J. 1983. The cranial muscles of loricariid catfishes, their homologies and value as taxonomic characters (Teleostei; Siluroidei). Bulletin of the British Museum (Natural History), Zoological Series, 45: 309-345.

Isbrücker, I. J. H. 1980. Classification and catalogue of the mailed Loricariidae (Pisces, Siluriformes). Verslagen en Technische Gegevens, 22: 1-181.

Konings, A. 1989. Malawi cichlids in their natural habitat. Verduijn Cichlids \& Lake Fish Movies, Pijnacker, 302 p.

Leviton, A. E., R. H. Gibbs Jr., E. Heal \& C. E. Dawson. 1985. Standards in herpetology and ichthyology. Part I. Standard symbolic codes for institutional resource collections in herpetology and ichthyology. Copeia, 1985: 802-832.

Lundberg, J. G. \& J. N. Baskin . 1969. The caudal skeleton of the catfishes, order Siluriformes. American Museum Novitates, 2398: 1-49.

Montoya-Burgos, J., S. Muller, C. Weber \& J. Pawlowski. 1997. Phylogenetic relationships between Hypostominae and Ancistrinae (Siluroidei; Loricariidae): first results from mitochondrial $12 \mathrm{~S}$ and $16 \mathrm{~S}$ rRNA gene sequences. Revue Suisse de Zoologie, 104(1): 185-198.

Montoya-Burgos, J., S. Muller, C. Weber \& J. Pawlowski.1998. Phylogenetic relationships of the Loricariidae (Siluriformes) based on mitochondrial rRNA gene sequences. Pp. 363-374 In: L. R. Malabarba, R.E. Reis, R. P. Vari, Z. M. S. Lucena \& C. A. S. Lucena (Eds.). Phylogeny and classification of neotropical fishes. Edipucrs, Porto Alegre. 603p.

Muller, S., L. H. Rapp Py-Daniel \& J. Zuanon.1994. Ancistrus ranunculus, a new species of loricariid fish (Siluriformes: Loricariidae) from the Xingú and Tocantins Rivers, Brazil. Ichthyological Exploration of Freshwaters, 5(4): 289-296.
Pothoff, T. 1984. Clearing and staining techniques. Pp. 35-37 In: H. G. Moser, W. J. Richards, D. M. Cohen, M. P. Fahay, A. W. Kendall, Jr., \& S. L. Richardson (Eds.). Ontogeny and Systematic of Fishes. Ahlstrom Symposium, American Society of Ichthyologists and Herpetologists, Gainesville. 760p.

Rapp Py-Daniel, L. H. 1989. Redescription of Parancistrus aurantiacus (Castelnau, 1855) and preliminary establishment of two new genera: Baryancistrus and Oligancistrus (Siluriformes, Loricariidae). Cybium, 13(3): 235-246.

Rapp Py-Daniel, L. H. 1997. Phylogeny of the neotropical armored catfishes of the subfamily Loricariinae (Siluriformes; Loricariidae). Unpublished Ph.D. Dissertation, University of Arizona, Tucson.

Regan, C. T. 1904. A monograph of the fishes of the family Loricariidae. Transactions of the Zoological Society of London, 17(3): 191-350, pls. 9-21.

Schaefer, S. A. 1986. Historical biology of the loricariid catfishes: phylogenetics and functional morphology. Unpublished Ph.D. Dissertation, University of Chicago, Chicago.

Schaefer, S. A. 1987. Osteology of Hypostomus plecostomus (Linnaeus), with a phylogenetic analysis of the loricariid subfamilies (Pisces; Siluroidei). Contributions to Science, 394: 1-31.

Yamaoka, K. 1997. Trophic ecomorphology of Tanganykan cichlids. Pp. 27-56 In: H. Kawanabe, M. Hori \& M. Nagoshi (Eds). Fish communities in Lake Tanganyika. Kyoto University Press, Kyoto. 298p.

Received July 2005

Accepted November 2005 